\title{
ANALISIS KUALITAS PELAYANAN PT JASA RAHARJA DENGAN METODE SERVQUAL
}

\author{
Enny Noegraheni Hindarwati; Anintia Jayasari \\ School of Business and Management, BINUS University \\ Jln. K.H. Syahdan No. 9, Palmerah, Jakarta Barat 11480 \\ enny_noegraheni@yahoo.com; tyaanin@yahoo.com
}

\begin{abstract}
In order to improve the image of insurance company, this study was done to find a picture of the accident victim's satisfaction with the service of insurance company Jasa Raharja. Descriptive quantitative research was conducted with a population of accident victims. Data were taken with questionnaires by 80 respondents and data analysis used SERVQUAL. The results showed that the overall levels of accident victim's satisfaction with the service of insurance company Jasa Raharja levels are disatisfied. This is evident from the value of the gap between perception and negative expectation. Dimensions of perceived service quality as dissatisfaction by the accident victims are the reliability, responsiveness, assurance, and empathy dimension. Result was obtained from this research gap between perception and expectation of service with a value of 0.0284. Therefore, it is suggested to the insurance company Jasa Raharja to improve services to accident victims, especially dimensions unsatisfactory service for accident victims.
\end{abstract}

Keywords: satisfaction, jasa raharja, service quality, perception, expectation

\begin{abstract}
ABSTRAK
Penelitian untuk meningkatkan citra perusahaan asuransi Jasa Raharja dilakukan dengan mencari tahu gambaran kepuasan korban kecelakaan terhadap pelayanan perusahaan asuransi Jasa Raharja. Penelitian kuantitatif deskriptif dilakukan dengan populasi korban kecelakaan. Data diambil dengan angket atau kuesioner sebanyak 80 responden dan analisis data menggunakan metode SERVQUAL. Hasil penelitian menunjukkan bahwa secara keseluruhan tingkat kepuasan korban kecelakaan terhadap pelayanan perusahaan asuransi Jasa Raharja berada level tidak puas. Hal ini terlihat dari nilai kesenjangan antara persepsi dan harapan yang negatif. Dimensi kualitas jasa yang dirasakan tidak puas oleh korban kecelakaan adalah dimensi reliabilitas, daya tanggap, jaminan, dan empati. Dari penelitian ini diperoleh hasil kesenjangan antara persepsi dengan harapan jasa dengan nilai sebesar -0,0284. Oleh karena itu, kepada pihak perusahaan asuransi Jasa Raharja disarankan untuk meningkatkan jasa terhadap korban kecelakaan, khususnya dimensi kualitas jasa yang dirasa tidak memuaskan bagi korban kecelakaan.
\end{abstract}

Kata kunci: kepuasan, jasa raharja, kualitas jasa, persepsi, harapan 


\section{PENDAHULUAN}

Dalam era globalisasi situasi perekonomian global terus berubah. Oleh karena itu, perusahaan harus dapat mengatur dan menyesuaikan sistem operasional dalam ekonomi global yang terus berubah. Dalam kondisi global yang selalu berubah, manajemen operasional selalu dihadapkan pada kondisi tersebut. Untuk pencapaian keputusannya, panduan yang diambil oleh manajemen operasi adalah planning, organizing, staffing, leading, dan controlling (Heizer \& Render, 2010:39).

Pelayanan merupakan salah satu faktor kunci keberhasilan bagi organisasi yang bergerak di bidang jasa. Terutama bagi PT Jasa Raharja, untuk mempertahankan keberadaannya di masyarakat, perusahaan perlu untuk meningkatkan kualitas jasa. Dengan begitu, masyarakat lebih memilih asuransi PT Jasa Raharja daripada perusahaan asuransi lainnya.

PT Jasa Raharja (Persero) merupakan salah satu perusahaan yang bergerak di bidang jasa asuransi sosial. Adanya penurunan kualitas jasa PT Jasa Raharja selama ini, berdasarkan hasil wawancara, Kepala Unit Kecelakaan, Iptu Donatus Wau (Jum'at, 7/06/2013), mengatakan bahwa pelayanan Jasa Raharja terbukti menurun. Hal itu disebabkan pelayanan Jasa Raharja yang masih belum optimal terkait dengan koordinasi dengan pihak kepolisian karena persyaratan untuk proses klaim jaminan sosial yang mengharuskan adanya laporan polisi jika terjadi kecelakaan. Yang kedua adalah sosialisasi ke masyarakat yang belum maksimal karena banyak masyarakat yang tidak mengetahui proses untuk mendapatkan jaminan sosial sehingga terkadang masyarakat beranggapan masih dipersulit oleh pihak Jasa Raharja.

Sehubungan dengan fakta tersebut, jika PT Jasa Raharja tidak dapat meningkatkan pelayanannya dan kalah bersaing dengan perusahaan asuransi lainnya bahkan kepercayaan masyarakat telah berkurang, hal ini akan mengakibatkan munculnya permintaan amandemen atau perubahan UU No 33 \& 34 Tahun 1964. Serta apabila PT Jasa Raharja tidak mampu meningkatkan kualitas jasanya, perusahaan asuransi sosial milik negara ditutup dan akan dibuka untuk umum. Untuk itu, penelitian ini bertujuan untuk mengetahui: (1) persepsi korban kecelakaan terhadap kualitas jasa di PT Jasa Raharja, (2) harapan korban kecelakaan terhadap kualitas jasa di PT Jasa Raharja, (3) kepuasan korban kecelakaan terhadap kualitas jasa di PT Jasa Raharja, (4) perbaikan yang efektif untuk peningkatan kualitas jasa di PT Jasa Raharja.

\section{Kajian Literatur}

Penelitian sebelumnya (Bala, Sandhu, \& Nagpal, 2011) menganalisis kualitas jasa asuransi jiwa dengan menggunakan metode Servqual. Lebih lanjut, hasil dari penelitian Mishra dan Shekhar (2010) dengan menggunakan Fuzzy menunjukkan bahwa ketika jumlah objek pengukuran makin banyak dan makin banyak dimensi yang digunakan, maka makin sulit untuk mengalkulasikan Fuzzy secara manual. Meskipun demikian, untuk menyelesaikan masalah ini dapat digunakan komputer yang terintegrasi dengan logika fuzzy. Hal ini dapat dilakukan untuk solusi yang lebih cepat dan kalkulasi yang lebih tepat dan hal ini dapat membantu untuk hemat waktu dan mengurangi kesalahan manusia dan bias.

Kemudian, dalam dimensi kualitas jasa, hasil penelitian Abukhalifeh dan Som (2012) menyatakan bahwa ketika seseorang mendapatkan persepsi tinggi terhadap suatu pelayanan jasa, seseorang itu akan menjadi pelanggan yang loyal namun ada situasi ketika seseorang memiliki ekspektasi yang lebih tinggi sehingga menjadi tantangan tersendiri bagi organisasi untuk memenuhinya. Sementara Butt dan de Run (2010) dengan menggunakan metode servqual membantu mereka dalam menganalisis pengembangan skala dan memberikan hasil yang sangat baik, yang dapat digunakan dalam kebijakan kesehatan yang lebih luas dan dalam praktiknya. Al-Zoubi (2013) dengan menganalisis kualitas jasa bagi loyalti pelanggan dapat membantu untuk mendapatkan efek atau pengaruh bagi customer loyalty. 


\section{METODE}

Tabel 1 menunjukkan metode yang digunakan dalam penelitian ini.

Tabel 1 Metode penelitian

\begin{tabular}{ccclc}
\hline $\begin{array}{c}\text { Tujuan } \\
\text { Penelitian }\end{array}$ & $\begin{array}{c}\text { Jenis } \\
\text { Penelitian }\end{array}$ & $\begin{array}{c}\text { Metode } \\
\text { Penelitian }\end{array}$ & \multicolumn{1}{c}{ Desain Penelitian } & \multicolumn{1}{c}{ Unit } \\
Analisis & Time \\
T-1 & Deskriptif & Survey & $\begin{array}{l}\text { Korban kecelakaan } \\
\text { (orang tertanggung Asuransi Jasa Raharja) }\end{array}$ & Cross-Sectional \\
T-2 & Deskriptif & Survey & $\begin{array}{l}\text { Korban kecelakaan } \\
\text { (orang tertanggung Asuransi Jasa Raharja) }\end{array}$ & Cross-Sectional \\
T-3 & Deskriptif & Analisis & $\begin{array}{l}\text { Korban kecelakaan } \\
\text { (orang tertanggung Asuransi Jasa Raharja) }\end{array}$ & Cross-Sectional \\
T-4 & $\begin{array}{l}\text { Pemecahan } \\
\text { Masalah }\end{array}$ & Analisis & Hasil Pembahasan & - \\
\hline
\end{tabular}

Sumber: Penulis 2014

T-1 mengukur persepsi korban kecelakaan terhadap kualitas jasa PT Jasa Raharja dengan metode survei. T-2 mengukur harapan korban kecelakaan terhadap kualitas jasa PT Jasa Raharja dengan metode survei. T-3 mengukur kepuasan korban kecelakaan terhadap kualitas jasa PT Jasa Raharja dengan menggunakan metode survei kemudian dianalisis dengan metode servqual. T-4 menganalisis masalah kemudian memberikan solusi untuk perbaikan yang tepat pada kualitas jasa PT Jasa Raharja.

Teknik pengumpulan data dilakukan dengan menggunakan kuesioner yang diberikan kepada responden yang berada di daerah Bandung, Jawa Barat, periode Januari hingga Oktober 2013. Populasi adalah objek penelitian yang mempunyai kualitas dan karakteristik yang ditetapkan dan kemudian ditarik simpulan (Sugiyono, 2010:72). Populasi dalam penelitian ini adalah para korban kecelakaan lalu lintas luka-luka dan meninggal yang diberikan santunan oleh Jasa Raharja. Teknik pengambilan sampel dilakukan dengan rumus Slovin (Kuncoro \& Riduwan, 2008:44). Jumlah sampel dalam penelitian ini adalah sebanyak 131,99 yang kemudian dibulatkan menjadi 132 sampel. Rancangan pemecahan hasil penelitian ini, yaitu setelah semua data telah terkumpul, data kuesioner akan diuji terlebih dahulu dengan menggunakan SPSS 20. Kemudian penelitian menganalisis persepsi dan harapan korban kecelakaan terhadap kualitas jasa PT Jasa Raharja dalam kelima dimensi kualitas jasa dengan menggunakan metode servqual.

Dari analisis tersebut, apabila nilai persepsi lebih besar daripada nilai harapan, nilai servqual positif. Artinya, para korban kecelakaan telah merasa puas terhadap kualitas jasa PT Jasa Raharja. Sebaliknya, jika nilai harapan lebih besar daripada nilai persepsi, menghasilkan nilai yang negatif. Artinya, para korban dinilai tidak merasa puas terhadap kualitas jasa PT Jasa Raharja. Teknik pengumpulan data dilakukan dengan studi lapangan (field research) melalui wawancara dan kuesioner dan studi pustaka (library research). 


\section{HASIL DAN PEMBAHASAN}

Kotler dan Armstrong (2012:248) mendefinisikan jasa sebagai suatu bentuk produk yang terdiri dari aktivitas, manfaat, atau kepuasan yang ditawarkan untuk dijual yang pada dasarnya tidak berwujud dan tidak mengakibatkan kepemilikan apapun. Jadi jasa merupakan kinerja (performance), tidak berwujud, dan lebih dapat dirasakan daripada dimiliki. Kondisi ini cepat ataupun lambat pertumbuhan jasa akan sangat bergantung pada penilaian pelanggan terhadap kinerja yang ditampilkan oleh produsen.

Menurut Tjiptono dan Chandra (2008:13) klasifikasi jasa adalah sebagai berikut. Pertama, segmen pasar, dibedakan menjadi jasa yang ditujukan pada konsumen akhir (taksi, asuransi jiwa, jasa tabungan, dan pendidikan) dan jasa bagi konsumen organisasi (contohnya: biro periklanan, jasa akuntansi dan perpajakan, dan jasa konsultasi manajemen). Kedua, tingkat keberwujudan: rentedgoods services, owned-goods services, non-goods services. Ketiga, Keterampilan Penyedia Jasa. Keempat, Tujuan Organisasi Penyedia Jasa. Kelima, Regulasi. Keenam, Tingkat Intensitas Karyawan. Ketujuh, Tingkat Kontak Penyedia Jasa dan Pelanggan.

Karakteristik jasa menurut Kotler dan Armstrong (2012:260) adalah sebagai berikut. Intangibility, jasa yang bersifat intangibility adalah jasa yang tidak bisa dilihat, dirasakan, didengar, maupun dicium sebelum dibeli dan dikonsumsi. Misalnya, orang yang akan melakukan operasi kecantikan tidak bisa melihat hasilnya sebelum ia dioperasi, penumpang pesawat tidak mendapatkan apa-apa selain tiket dan janji bahwa barang bagasi yang dibawa datang dengan selamat pada tujuan dan jam yang sama saat penumpang tiba. Pelanggan inilah yang menyimpulkan tentang bagaimana kualitas dari tempat, orang, harga, peralatan, dan komunikasi yang mereka lihat tentang perusahaan tersebut. Inseparability, jasa yang bersifat inseparability adalah jasa yang diproduksi dan dikonsumsi pada saat yang bersamaan dan tidak bisa dipisahkan dari penyedia jasanya, misalnya: praktik dokter, dokter gigi tersebut tidak dapat memproduksi jasanya tanpa kehadiran pasien. Variability, karakteristik variability pada jasa adalah kualitas jasa tergantung pada siapa yang menyediakannya, kapan, di mana, dan bagaimana jasa tersebut diproduksi. Contohnya, hotel Marriots yang memiliki reputasi yang lebih baik dalam pelayanannya, karyawan resepsionis yang berada di counter ramah dan cepat pelayanannya, tetapi karyawan yang pengangkut barang (bell boy) terkesan tidak ramah dan lamban. Perishability, karakteristik jasa ini menggambarkan bahwa jasa tidak bisa disimpan dan tidak bisa tahan lama untuk digunakan dan dijual diwaktu mendatang, dijual kembali atau dikembalikan. Misalnya, kursi pesawat yang kosong, kamar hotel yang tidak dihuni, atau jam tertentu tanpa pasien di tempat praktik dokter umum akan berlalu atau hilang begitu saja karena tidak bisa disimpan.

Definisi kualitas jasa sebagai ukuran seberapa bagus tingkat layanan yang diberikan mampu menyesuaikan dengan ekspetasi pelanggan. Kualitas bisa diwujudkan melalui pemenuhan kebutuhan dan keinginan pelanggan serta ketepatan penyampaiannya untuk mengimbangi harapan pelanggan (Tjiptono \& Chandra, 2008:121). Dua faktor utama yang memengaruhi kualitas jasa yaitu jasa yang diharapkan (expected service) dan jasa yang dirasakan/dipersepsikan (perceived service). Apabila jasa yang dirasakan sesuai dengan jasa yang diharapkan, kualitas jasa tersebut akan dipersepsikan dengan baik atau positif. Jika jasa yang dirasakan melebihi jasa yang diharapkan, kualitas jasa dipersepsikan secara ideal. Sebaliknya kualitas jasa akan dipersepsikan dengan buruk atau negatif jika jasa yang dirasakan lebih jelek dibandingkan jasa yang diharapkan. Oleh sebab itu, baik atau tidaknya kualitas jasa tergantung pada kemampuan penyedia jasa dalam memenuhi harapan pelanggannya secara konsisten (Tjiptono \& Chandra, 2008:121).

Dimensi kualitas jasa sebagai berikut. Reliabilitas (Reliability) adalah kemampuan penyedia jasa untuk memberikan layanan yang akurat sejak pertama kali tanpa membuat kesalahan apapun dan menyampaikan jasanya sesuai dengan waktu yang disepakati. Daya Tanggap (Responsiveness), 
berkaitan dengan kesediaan dan kemampuan para karyawan untuk membantu para pelanggan dan merespons permintaannya, serta menginformasikan kapan jasa akan diberikan dan kemudian memberikan jasa secara cepat. Jaminan (Assurance), perilaku para karyawan mampu menumbuhkan kepercayaan pelanggan dan perusahaan bisa menciptakan rasa aman bagi para pelanggannya. Dalam hal ini perilaku karyawan yang dimaksud adalah dengan bersikap sopan dan menguasai pengetahuan dan keterampilannya dalam menangani setiap pertanyaan atau masalah pelanggan. Empati (Emphaty), perusahaan memahami masalah pelanggan dan bertindak demi kepentingan pelanggan, serta memberikan perhatian personal kepada para pelanggan dan memiliki jam operasi yang nyaman. Bukti fisik (Tangibles) meliputi daya tarik fasilitas fisik, perlengkapan, dan material yang digunakan perusahaan, serta penampilan karyawannya.

Metode Service Quality merupakan model pengukuran Gap kualitas pelayanan atau jasa yang diperkenalkan oleh Zeithaml, Parasuraman, dan Berry pada 1985 (Gaspersz, 2012:86). Metode ini banyak digunakan untuk mengukur kepuasan pelanggan. Metode yang dikenal pula dengan istilah Gap Analysis Model ini berkaitan erat dengan model kepuasan pelanggan yang didasarkan pada pendekatan diskonfirmasi. Pendekatan ini menegaskan bahwa bila kinerja meningkat lebih besar daripada harapan, maka persepsi terhadap kepuasan jasa akan positif dan sebaliknya. Metode servqual (service quality) ini dikembangkan dengan maksud untuk membantu para manajer dalam menganalisis sumber masalah kualitas jasa dan memahami cara-cara memperbaiki kualitas jasa (Tjiptono \& Chandra, 2008:145).

Kesenjangan (gap) Kualitas Jasa, terdiri dari lima gap utama. Pertama, gap antara harapan pelanggan dengan persepsi manajemen (knowledge gap). Gap ini berarti bahwa pihak manajemen mempersepsikan ekspektasi pelanggan terhadap kualitas jasa secara tidak akurat. Kedua, gap antara persepsi manajemen terhadap harapan konsumen dan spesifikasi kualitas jasa (standards gap). Gap ini menunjukkan bahwa spesifikasi kualitas jasa tidak konsisten dengan persepsi manajemen terhadap ekspektasi kualitas. Penyebabnya adalah tidak adanya standar kinerja yang jelas, kesalahan perencanaan atau prosedur perencanaan yang tidak memadai, manajemen perencanaan yang buruk, kurangnya penetapan tujuan yang jelas dalam organisasi, kurangnya dukungan dan komitmen manajemen puncak terhadap perencanaan kualitas jasa, kekurangan sumber daya, dan situasi permintaan yang berlebihan. Ketiga, gap antara spesifikasi kualitas jasa dan penyampaian jasa (delivery gap). Gap ini berarti bahwa spesifikasi kualitas tidak terpenuhi oleh kinerja dalam proses produksi dan penyampaian jasa. Keempat, gap antara penyampaian jasa dan komunikasi eksternal (communications gap). Gap ini berarti bahwa janji-janji yang disampaikan oleh penyedia jasa tidak konsisten dengan jasa yang disampaikan kepada para pelanggan. Kelima, gap antara jasa yang dipersepsikan dan jasa yang diharapkan (service gap). Gap ini berarti bahwa jasa yang dipersepsikan tidak konsisten dengan jasa yang diharapkan. Gap ini bisa menimbulkan konsekuensi yang negatif.

Melalui analisis terhadap berbagai skor gap ini, akan dihasilkan output yang sangat berguna bagi perusahaan asuransi PT Jasa Raharja untuk mengetahui faktor penentu servqual di perusahaan. Dengan menggunakan output tersebut, perusahaan tidak hanya bisa menilai kualitas jasa keseluruhannya sebagaimana yang dipersepsikan korban kecelakaan, tetapi juga bisa mengidentifikasi mana sajakah antara 25 indikator yang membutuhkan penyempurnaan kualitas. Dengan begitu, perusahaan dapat berfokus pada indikator yang paling kuat dan memperkuat strategi mana yang tepat. Dengan adanya gambaran rancangan penelitian (Gambar 1), maka penelitian ini dapat digunakan sebagai bahan evaluasi mengenai peningkatan kualitas jasa PT Jasa Raharja terhadap korban kecelakaan. Hal itu dimaksudkan agar korban kecelakaan merasa puas terhadap jasa perusahaan, sehingga dapat meningkatkan citra professional (corporate image), keberlangsungan operasional perusahaan terjamin, dan kebutuhan korban kecelakaan terpenuhi. 


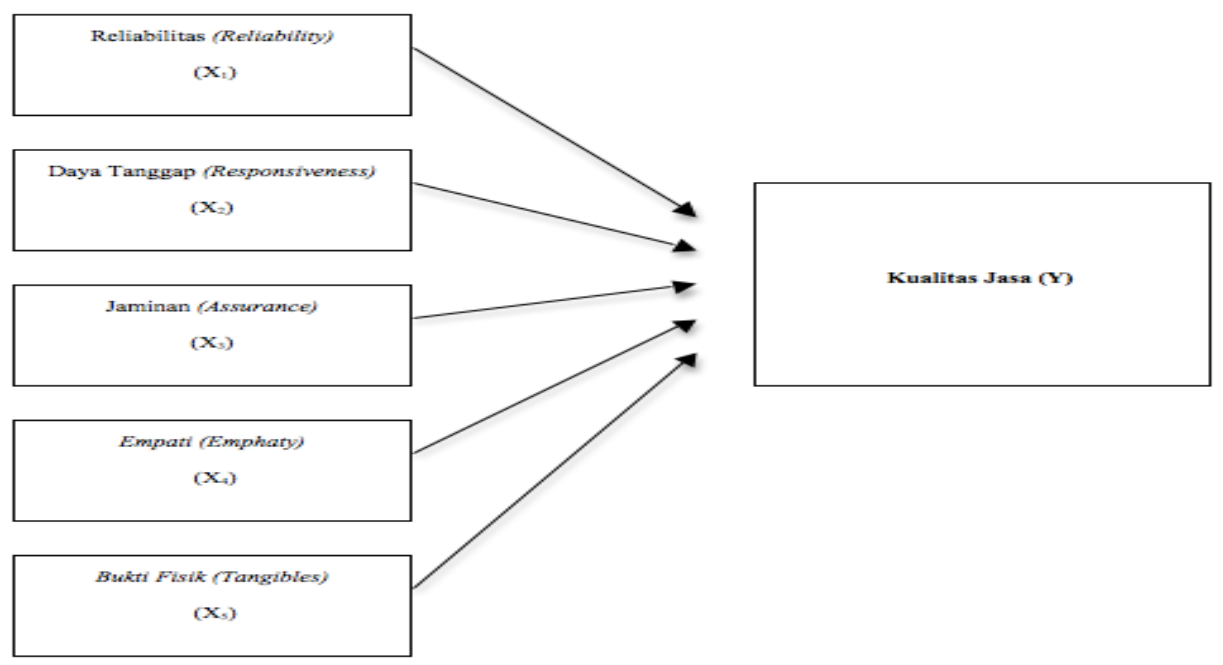

Gambar 1 Kerangka Pemikiran

(Sumber: Penulis 2014)

Uji validitas pada penelitian ini menggunakan taraf signifikan 5\% dan $\mathrm{N}=30$ sampel maka $\mathrm{r}$ tabel $=0,31$. Data dikatakan valid jika nilai $\mathrm{R}_{\text {hasil }}>\mathrm{R}$ table $\mathrm{Uji}$ reliabilitas data dalam penelitian ini dilakukan dengan menggunakan SPSS 20. Dengan melihat nilai koefisien Cronbach's Alpha> nilai tabel, maka pernyataan-pernyataan yang ada dalam kuesioner dapat dikatakan reliable.

Tabel 2 Uji Reliabilitas Data

\begin{tabular}{lccc}
\hline Variabel & Cronbach's Alpha & R tabel & Keterangan \\
\hline Harapan & 0,933 & 0,31 & Reliable \\
Tanggapan & 0,933 & 0,31 & Reliable \\
Persepsi & 0,935 & 0,31 & Reliable \\
\hline
\end{tabular}

Sumber: Hasil Pengolahan Data

Dalam tahap pengumpulan data, penyebaran kuesioner dilakukan di wilayah Bandung, Jawa Barat. Data yang disebarkan melalui 132 responden periode Januari hingga September 2013 hanya dapat terkumpul sebanyak 80 data karena data alamat responden yang didapatkan dari PT Jasa Raharja kurang jelas. Selain itu, banyak faktor lain yang membatasi peneliti untuk mendapatkan 132 data. Berdasarkan hasil pengolahan data, didapatkan hasil profil responden berdasarkan jenis kelamin, sebagai berikut:

Tabel 3 Profil Responden Berdasarkan Jenis Kelamin

\begin{tabular}{lcc}
\hline \multicolumn{1}{c}{ Jenis Kelamin } & Jumlah & Presentase \\
\hline Pria & 54 & $67,5 \%$ \\
Wanita & 26 & $32,5 \%$ \\
\hline \multicolumn{1}{c}{ Total } & 80 & $100 \%$ \\
\hline
\end{tabular}

Sumber: Hasil pengolahan data

Tabel 3 menunjukkan bahwa reponden pria sebanyak 54 orang sedangkan wanita sebanyak 26 orang. 
Berdasarkan dari hasil pengolahan data responden yang berdasarkan usia, maka diperoleh sebagai berikut:

Tabel 4 Profil Responden Berdasarkan Usia

\begin{tabular}{ccc}
\hline Usia & Jumlah & Presentase \\
\hline$\leq 17$ tahun & 1 & $1,3 \%$ \\
$\geq 54$ tahun & 5 & $6,3 \%$ \\
$17-25$ tahun & 15 & $18,8 \%$ \\
$26-34$ tahun & 25 & $31,3 \%$ \\
$35-43$ tahun & 17 & $21,3 \%$ \\
$44-53$ tahun & 17 & $21,3 \%$ \\
\hline Total & 80 & $100 \%$ \\
\hline
\end{tabular}

Sumber: Hasil Pengolahan Data

Tabel 4 menunjukkan bahwa responden yang paling banyak adalah responden yang berumur antara 26 - 34 tahun sebanyak 25 orang. Sedangkan yang paling sedikit adalah sebanyak 1 orang responden yang berumur di bawah 17 tahun.

Data profil responden berdasarkan tingkat pendidikan, sebagai berikut.

Tabel 5 Profil Responden Berdasarkan Tingkat Pendidikan

\begin{tabular}{lcc}
\hline Tingkat Pendidikan & Jumlah & Presentase \\
\hline S1 & 8 & $10 \%$ \\
SMA & 56 & $70 \%$ \\
SMP & 13 & $16,2 \%$ \\
Tidak Sekolah & 3 & $3,8 \%$ \\
\hline \multicolumn{1}{r}{ Total } & 80 & $100 \%$ \\
\hline
\end{tabular}

Sumber: Hasil Pengolahan Data

Dari tabel profil responden berdasarkan tingkat pendidikan, sebagian besar tingkat pendidikan responden adalah SMA sebanyak 56 orang, pendidikan setingkat S1 sebanyak 8 orang, pendidikan setingkat SMP sebanyak 13 orang, dan responden yang tidak sekolah sebanyak 3 orang.

Data profil responden yang dilihat dari status kecelakaannya, sebagai berikut.

Tabel 6 Profil Responden Berdasarkan Status Korban Kecelakaan

\begin{tabular}{ccc}
\hline $\begin{array}{c}\text { Status Korban } \\
\text { Kecelakaan }\end{array}$ & Jumlah & Persentase \\
\hline Luka - Luka & 23 & $28,8 \%$ \\
Meninggal Dunia & 57 & $71,2 \%$ \\
\hline Total & 80 & $100 \%$ \\
\hline
\end{tabular}

Sumber: Hasil Pengolahan Data 2014

Dari tabel profil responden berdasarkan status korban kecelakaan, yang paling tinggi angka terjadinya kecelakaan adalah meninggal dunia sebanyak 57 orang. Sedangkan kecelakaan yang hanya menyebabkan korban luka-luka 23 orang. 
Berdasarkan hasil pengolahan data profil responden waktu tempat kejadian perkara, adalah sebagai berikut:

Tabel 7 Profil Responden Berdasarkan Waktu Kejadian

\begin{tabular}{ccc}
\hline $\begin{array}{c}\text { Waktu } \\
\text { Kejadian }\end{array}$ & Jumlah & Presentase \\
\hline Apr-13 & 15 & $18,8 \%$ \\
Aug-13 & 7 & $8,8 \%$ \\
Feb-13 & 5 & $6,3 \%$ \\
Jan-13 & 3 & $3,8 \%$ \\
Jul-13 & 7 & $8,8 \%$ \\
Jun-13 & 9 & $11,3 \%$ \\
Mar-13 & 11 & $13,8 \%$ \\
May-13 & 10 & $12,5 \%$ \\
Oct-13 & 2 & $2,5 \%$ \\
Sep-13 & 11 & $13,8 \%$ \\
\hline Total & 80 & $100 \%$ \\
\hline
\end{tabular}

Sumber: Hasil Pengolahan Data 2014

Dari tabel profil responden berdasarkan waktu kejadiannya, angka kejadian kecelakaan tertinggi jatuh pada April 2013, sebanyak 15 kali kejadian. Sedangkan angka yang paling minim terjadi kecelakaannya adalah pada Oktober 2013, sebanyak 2 kali kejadian.

Berdasarkan hasil pengolahan data profil responden yang dilihat dari tempat kejadian kecelakaan adalah sebagai berikut.

Tabel 8 Profil Responden Berdasarkan Tempat Kejadian

\begin{tabular}{lcc}
\hline Tempat Kejadian & Frekuensi & Presentase \\
\hline Bandung & 9 & $11,3 \%$ \\
Buah Batu & 5 & $6,3 \%$ \\
Jl. Jakarta & 5 & $6,3 \%$ \\
Jl. Sukarno Hatta & 5 & $6,3 \%$ \\
Jl. Suci & 4 & $5 \%$ \\
\hline
\end{tabular}

Sumber: Hasil Pengolahan Data

Dari tabel profil responden yang dilihat dari tempat kejadiannya, urutan pertama tempat kejadian yang tertinggi adalah Kota Bandung, sebanyak 9 kejadian. Kemudian Buah Batu, Jl. Jakarta, Jl. Sukarno Hatta, memiliki frekuensi kejadian yang sama yaitu sebanyak 5 kejadian, sedangkan Jl. Suci sebanyak 4 kejadian.

Berikut ini adalah hasil pengolahan data responden berdasarkan santunan yang diberikan, yaitu sebagai berikut.

Tabel 9 Profil Responden Berdasarkan Santunan yang Diberikan

\begin{tabular}{ccc}
\hline Santunan & Jumlah & Persentase \\
\hline Sudah Diberikan & 80 & $100 \%$ \\
Belum Diberikan & 0 & $0 \%$ \\
\hline Total & 80 & $100 \%$ \\
\hline
\end{tabular}

Sumber: Hasil Pengolahan Data 2014 
Dari tabel profil responden berdasarkan santunan yang diberikan, diperoleh persentase sebesar $100 \%$ dengan jumlah responden sebanyak 80 orang yang telah diberikan santunan oleh Jasa Raharja, dan tidak ada responden yang belum diberikan santunan oleh Jasa Raharja.

Rentang waktu kejadian pada periode Januari hingga Oktober 2013 lebih banyak menyebabkan korban meninggal dunia daripada luka-luka. Waktu kejadian yang paling banyak terjadi adalah pada April 2013 karena pada bulan tersebut tidak memiliki tanggal merah atau hari libur yang panjang. Artinya aktivitas masyarakat Bandung sangat padat. Di samping itu, menurut BMKG cuaca pada April 2013 wilayah Indonesia, termasuk wilayah Jawa Barat, memasuki musim hujan dan musim kemarau (pancaroba) yang ditandai dengan cuaca tak menentu seperti cuaca panas terik di siang hari dan hujan lebat di sore hari yang merupakan gangguan cuaca akibat dari pergeseran pemanasan matahari. Perubahan suhu udara ini mengakibatkan gangguan kesehatan jasmani seperti influenza, demam berdarah, diare, dan gangguan saluran pernafasan (ISPA). Oleh karena itu, dengan kondisi cuaca seperti ini masyarakat Jawa Barat tidak memiliki kondisi jasmani yang fit dan kesehatan terganggu, serta cuaca yang tidak menentu dapat mengganggu konsentrasi setiap individu yang mengendarai kendaraan, sehingga hal ini menyebabkan tingkat kecelakaan tertinggi pada April 2013.

Tempat kejadian dengan angka frekuensi tertinggi adalah kota Bandung. Hal ini disebabkan ramainya kendaraan lalu lintas di kota Bandung yang dapat menimbulkan kecelakaan. Sementara itu, santunan dana telah diberikan oleh pihak perusahaan asuransi PT Jasa Raharja. Korban kecelakaan rata-rata telah mengakui bahwa memang benar santunan dana telah diberikan santunan dana sesuai dengan jumlah dana yang seharusnya diberikan oleh Jasa Raharja.

Dalam penelitian ini, nilai kesenjangan persepsi dan harapan (servqual) dihitung berdasarkan per item pernyataan dari kuesioner ke dalam lima dimensi tersebut. Item ini dikelompokkan ke lima dimensi, kemudian dihitung nilai rata-rata servqual. Maka diperoleh hasil nilai kesenjangan antara persepsi dan harapan (servqual), yaitu seperti berikut ini.

Tabel 10 Perhitungan Nilai Kesenjangan Persepsi dan Harapan (Servqual) Keseluruhan

\begin{tabular}{clcccc}
\hline No & \multicolumn{1}{c}{ Dimensi } & Persepsi & Harapan & Servqual & Ranking \\
\hline 1 & Reliabilitas (Reliability) & 3,926 & 4,002 & $-0,076$ & $\mathbf{1}$ \\
2 & Daya Tanggap (Responsiveness) & 3,864 & 3,92 & $-0,056$ & 2 \\
3 & Jaminan (Assurance) & 3,968 & 3,97 & $-0,002$ & 4 \\
4 & Empati (Emphaty) & 3,914 & 3.922 & $-0,008$ & 3 \\
5 & Bukti Fisik (Tangibles) & 3,934 & 3,934 & 0 & 5 \\
\hline & JUMLAH & $19,606 / 5$ & $19,748 / 5$ & $-0,142 / 5$ & \\
& $=\mathbf{3 , 9 2 1 2}$ & $=\mathbf{3 , 9 4 9 6}$ & $\mathbf{- 0 , 0 2 8 4}$ & \\
\hline
\end{tabular}

Sumber: Hasil Pengolahan Data 2014

Penilaian mengenai jasa dengan menggunakan rumus (Ispurwanto \& Pricillia, 2011): Kp = Pp / Ex.

Korban kecelakaan dikatakan puas jika harapannya terpenuhi dan tidak puas jika harapan tidak terpenuhi. Dengan menggunakan kategori di bawah ini akan menjadi jelas apakah korban puas atau tidak puas terhadap kualitas jasa PT Jasa Raharja. Kategori tersebut adalah sebagai berikut:
1. Sangat tidak puas kategori 1
$0,0 \mathrm{~s} / \mathrm{d} 0,50$
2. Tidak puas
kategori 2
$0,51 \mathrm{~s} / \mathrm{d} 0,74$
3. Cukup puas
kategori 3
$0,75 \mathrm{~s} / \mathrm{d} 0,99$
4. Puas
5. Sangat puas
kategori $4 \quad 1$
kategori $5 \quad>1$. 
Tabel 11 Pengukuran Kepuasan Korban Kecelakaan

\begin{tabular}{clcccc}
\hline No & \multicolumn{1}{c}{ Dimensi } & Persepsi & Harapan & Kepuasan & Ranking \\
\hline 1 & Reliabilitas (Reliability) & 3,926 & 4,002 & 0,9810 & 1 \\
2 & Daya Tanggap (Responsiveness) & 3,864 & 3,92 & 0,9857 & 2 \\
3 & Jaminan (Assurance) & 3,968 & 3,97 & 0,9994 & 4 \\
4 & Empati (Emphaty) & 3,914 & 3.922 & 0,9979 & 3 \\
5 & Bukti Fisik (Tangibles) & 3,934 & 3,934 & 1 & 5 \\
\hline & & $19,606 / 5$ & $19,748 / 5$ & $\mathbf{0 , 9 9 2 8}$ & \\
\hline
\end{tabular}

Sumber: Hasil Pengolahan Data

Berdasarkan pada hasil pengujian kesenjangan antara persepsi dan harapan (servqual), di antara kelima dimensi kualitas jasa tersebut yang memiliki nilai gap terendah adalah dimensi reliabilitas. Serta pernyataan dari dimensi reliabilitas yang paling rendah adalah berkaitan dengan santunan dana yang diterima korban kecelakaan yang diberikan oleh pihak petugas asuransi Jasa Raharja. Hal ini ditandai dengan fakta yang sudah dialami oleh korban kecelakaan bahwa rata-rata korban kecelakaan pada umumnya mengakui dalam mengurusi klaim asuransi ini menggunakan jasa calo. Nilai nominal santunan dana untuk korban kecelakaan meninggal dunia adalah sebesar Rp25.000.000,00 dan untuk korban kecelakaan luka-luka adalah sebesar Rp10.000.000,00. Ketika dianalisis lebih lanjut, adanya ketidaksesuaian antara data perusahaan dan data profil responden pada lembar kuesioner yang diisi langsung oleh respondennya, yaitu terlihat pada status korban kecelakaan tersebut merupakan meninggal dunia yang ditulis pada data PT Jasa Raharja, sedangkan pada data profil responden ditulis status korban kecelakaan tersebut adalah luka-luka dan sebaliknya. Oleh karena itu, korban kecelakaan merasa santunan dana yang diterima kurang atau tidak utuh dan tidak sesuai dengan yang dijanjikan oleh pihak PT Jasa Raharja.

Dimensi kedua yang dirasakan rendah bagi korban kecelakaan adalah daya tanggap (responsiveness). Hal itu ditandai dengan pernyataan terendah di dimensi ini, yaitu mengenai petugas yang mendatangi rumah korban kecelakaan untuk menjelaskan tentang hak-hak korban dalam mengurus klaim. Hal ini menunjukkan bahwa kurangnya pelatihan bagi petugas asuransi Jasa Raharja mengenai kecepatannya dalam menanggapi korban kecelakaan.

Pada dimensi jaminan (assurance) dinilai tidak memuaskan, yang ditandai dengan rendahnya kesadaran petugas Jasa Raharja yang ramah dalam melayani korban kecelakaan. Hal ini berkaitan dengan karakter dan kepribadian serta kurangnya pelatihan petugas Jasa Raharja dalam melayani korban kecelakaan. Tentunya korban kecelakaan merasa tidak nyaman atau aman dengan sikap petugas yang tidak ramah dalam melayani korban kecelakaan, sehingga dimensi ini masih dirasakan tidak puas.

Selanjutnya, dimensi empati (emphaty) juga dirasakan oleh korban kecelakaan kurang memuaskan, terutama pada pernyataan mengenai petugas asuransi yang mendengarkan keluhan korban dengan penuh perhatian. Hal ini disebabkan oleh petugas yang kurang dilatih oleh PT Jasa Raharja dalam berempati dan ikut merasakan apa yang dirasakan oleh korban kecelakaan yang terkena musibah, serta keluhan-keluhan yang berkaitan dengan kualitas jasa PT Jasa Raharja.

Pemecahan solusi pada keempat dimensi tersebut yang dapat digunakan untuk perbaikan PT Jasa Raharja, adalah sebagai berikut. Pertama, dimensi Reliabilitas (Reliability) dengan mendidik korban kecelakaan (klaimen) tentang kualitas jasa PT Jasa Raharja, membantu korban kecelakaan dalam memahami jasa perusahaan untuk mewujudkan proses penyampaian jasa secara efektif dan efisien, sehingga korban kecelakaan yang terdidik akan dapat mengambil keputusan yang baik untuk menggunakan calo atau tidak yang dapat merugikan pihak korban kecelakaan, sehingga kepuasan mereka dapat tercipta lebih tinggi. Menambah 24 jam kantor pelayanan di hari libur seperti Sabtu dan 
Minggu, agar korban kecelakaan dapat mengajukan permohonan santunan dana langsung dengan sendirinya tanpa melalui calo. Selain itu menciptakan budaya konsisten bagi petugas asuransi sehingga dapat diandalkan atau dipercaya dalam menjalani tugasnya, serta menelaah kembali rantai prosedur operasional dalam menyerahkan santunan dana atau diterimanya santunan dana pada korban kecelakaan tersebut. Kedua, dimensi Daya Tanggap (Responsiveness) dengan cara pengembangan individual, dilakukan dengan menyusun instruksi pekerjaan, sehingga setiap petugas dapat memperoleh keterampilan dan pengetahuan teknis yang diperlukan dalam menjalankan tugasnya sesuai posisi atau jabatannya, juga meningkatkan kecepatan daya tanggap dengan melatih dan mengawasi petugas ketika menghadapi korban kecelakaan. Ketiga, dimensi Jaminan (Assurance) dengan cara standar Kinerja, PT Jasa Raharja dapat menyusun pedoman yang berisi instruksi dan prosedur melaksanakan suatu tugas, misalnya cara menyapa korban kecelakaan, cara melayani korban kecelakaan, bersikap ramah kepada korban kecelakaan, dan sebagainya Juga melatih petugas untuk tetap bersikap profesional dalam menjalani tugasnya, dengan cara pihak perusahaan asuransi memberi arahan atau teguran bagi petugas yang tidak ramah. Selain itu, pihak perusahaan menyediakan sistem polling atau poin dari korban kecelakaan untuk penilaian petugas yang melayani korban kecelakaan tersebut. Keempat, dimensi Empati (Emphaty), melatih petugas dengan meningkatkan rasa empatinya dan luwes terhadap korban kecelakaan, dengan memberikan instruksi atau pengarahan yang harus dilakukan ketika berhadapan dengan keluhan-keluhan dari korban kecelakaan, sehingga dapat memberikan jalan keluar yang baik terhadap keluhan-keluhan korban kecelakaan.

\section{SIMPULAN}

Berdasarkan tujuan penelitian yang ingin dicapai pada penelitian ini, dapat disimpulkan bahwa persepsi korban kecelakaan terhadap kualitas jasa di PT Jasa Raharja rata-rata sebesar 3,9212. Harapan korban kecelakaan terhadap kualitas jasa di PT Jasa Raharja rata-rata sebesar 3,9496. Tingkat kepuasan korban kecelakaan berdasarkan gap yang ada antara persepsi dan harapan (servqual) yang paling rendah adalah sebesar -0,076, yaitu pada dimensi reliabilitas (reliability) yang berkaitan dengan santunan dana korban kecelakaan. Perbaikan kualitas jasa di PT Jasa Raharja yang memfokuskan pada unit pelayanan dan bagian keuangan.

Berdasarkan simpulan tersebut, berikut ini adalah beberapa saran untuk perbaikan kualitas jasa di PT Jasa Raharja pada dimensi Reliabilitas (Reliability) yaitu memberikan brosur tentang prosedur pengajuan klaim kepada korban kecelakaan. Pada bagian keuangan yaitu kasir, santunan dana diberikan melalui rekening korban kecelakaan daripada diberikan secara tunai guna untuk meminimalkan terjadinya kecurangan oleh pihak ketiga. Untuk dimensi Daya Tanggap (Responsiveness), yaitu pelatihan kerja (training), seminar dan lokakarya (workshop) pada unit pelayanan. Pada dimensi Jaminan (Assurance) dan dimensi Empati (Emphaty) adalah pelatihan (training) pada petugas asuransi di unit pelayanan dapat diberikan melalui training khusus yaitu kursus kepribadian.

\section{DAFTAR PUSTAKA}

Abukhalifeh, A. N., \& Som, A. P. M. (2012). Service quality management in hotel industries: A conceptual framework for food and beverage departments. International Journal of Business and Management, 7(14), 135-141. doi: 10.5539/ijbm.v7n14p135

Al-Zoubi, M. R. (2013). Service quality effects on customer loyalty among the Jordanian telecom sector "Empirical Study". International Journal of Business and Management, 8(7), 35-45. doi: 10.5539/ijbm.v8n7p35. 
Bala, N., Sandhu, H. S., \& Nagpal, N. (2011). Measuring life insurance service: An empirical assessment of servqual instrument. International Business Research, 4(4), 176-190.

Butt, M. M., \& de Run, E. C. (2010). Private healthcare quality: applying a SERVQUAL model. International Journal of Health Care Quality Assurance, 23(7), 658-673. doi: http://dx.doi.org/10.1108/09526861011071580

Gaspersz, V. (2012). All in One Management Toolbook. Bogor: Tri Albros.

Heizer, J. \& Render, B. (2010). Operations Management Global Edition. 10th Edition.Canada: Pearson.

Ispurwanto, W. \& Pricillia, V. W. (2011). Analisis Kepuasan Penumpang Gerbong Kereta Api Khusus Wanita Menggunakan Metode Servqual. Thesis Program Pascasarjana, Universitas Bina Nusantara.

Kotler, P. \& Armstrong, G. (2012). Principles of Marketing. 14th Edition. United States: Pearson.

Kuncoro, A. E. \& Riduwan. (2008). Cara Menggunakan dan Memaknai Analisis Jalur (Path Analysis). Bandung: Alfabeta.

Mishra, P. K., \& Shekhar, B. R. (2010). Measuring quality of service in retail outlets using fuzzy numbers. Management Science and Engineering, 4(3), 80-86. doi: http://dx.doi.org/10.3968\%2Fj.mse.1913035X20100403.008

Sugiyono. (2010). Statistika untuk Penelitian. Bandung: Alfabeta.

Tjiptono, F. \& Chandra, G. (2008). Service, Quality, \& Satisfaction. Edisi 2. Yogyakarta: Andi. 